\title{
THE CURRENT SITUATION AND ISSUES WITH ENGLISH LANGUAGE ACTIVITIES IN PRIMARY SCHOOLS IN JAPAN AFTER SIX YEARS OF IMPLEMENTATION
}

\author{
Takiguchi Masaru1,+, \\ Machida Junko ${ }^{2}$
}

\section{Article History}

Received: December 18, 2019

Accepted: February 02, 2020

Published: March 30, 2020

\section{Keywords}

English language activities, primary school, survey, homeroom teachers

\author{
${ }^{1}$ Shiraume Gakuen Junior College; ${ }^{2}$ Shiraume Gakuen University \\ ${ }^{+}$Corresponding author $\bullet$ Email: takiguchi-masaru@iaa.itkeeper.ne.jp
}

\section{INTRODUCTION}

English Language Activities (hereinafter called EL Activities) commenced in April, 2011 in the $5^{\text {th }}$ and $6^{\text {th }}$ grades of all public primary schools in Japan. This was the first time in Japan that English education was implemented in public primary schools. Lessons are only held once a week, but ordinary homeroom teachers have been required to teach English even though they are not skilled in it.

EL Activities are not considered a separate academic subject but, rather, an area or field of learning, according to the Course of Study for Primary School decided by the Ministry of Education, Culture, Sports, Science and Technology (MEXT).

In 2012, we researched some primary schools in the Tokyo Metropolitan Government regarding the program of EL Activities that had started just one year before. Then, we researched primary schools' EL Activities throughout Japan in 2014, three years after the program had started. There were some major problems. There were almost no English teachers to teach EL Activities. Classroom teachers were required to teach English even though they did not like English or did not have sufficient training. The Ministry of Education told the boards of education to use native English-speaking teachers in the study. But the ability to do that depended on the local governments' financial situation because the national government could not allocate the funds to hire them. Not every school had good teaching materials. Moreover, there were problems in training teachers.

Six years had passed since EL Activities began in 2011. Therefore, we again attempted to research primary schools throughout Japan regarding their EL Activities after six years of implementation. Six years' implementation of the EL Activities program was meant to determine whether it's a suitable program or not for children.

In this paper, we would like to demonstrate the changing situation of English education in primary schools in Japan by comparing the results of our surveys done in 2014 and 2017, respectively. We also would like to analyze the issues that stood out in the surveys.

\section{LITERATURE REVIEW}

During those six years of implementation of EL Activities, some analyses about the issues and the results from similar kinds of surveys were delivered as follows.

Firstly, MEXT examined the situations of the implementation (MEXTb, 2016). However, they studied only the local governments' policies and did not deal with the states of classroom lessons except using Information and Communication Technology (ICT). 
Secondly, a private think-tank researched about the EL activities and it also showed the possibility of using ICT (Eiken Foundation of Japan, 2015). This research asked for comments on the methods and the contents of EL Activities, but did not inform us about the actual situations of the lessons and teachers. Moreover, even though the research was conducted among not only public primary schools but also private primary schools and national primary schools, it did not mention correlations between teaching environments of those schools and results.

Benesse Education General Institute also researched about English education in primary schools in Japan in 2015. They questioned more than 1500 pairs of primary school students and their parents, but did not include primary school teachers.

In contrast, Yonezaki, Tara and Tsukuda (2016) researched primary school teachers' anxiety about teaching English and provided specific recurring examples of their anxieties. This was informative and useful to confirm our research results.

We also studied one of the latest research papers on the issue "Insights from Elementary School Assistant Language Teachers (ALTs) in Japan” (Kano \& Ozeki, 2018). This study analyzed ALT's' descriptive answers reported in the large-scale research (Yoshida, et al. 2015). When focusing solely on ALTs' situations, their analysis is greatly suggestive.

However, unlike the above, our research dealt with the situations of primary school teachers, ALTs and English Activity supporters (EASs). Furthermore, we attempted to find out how their situations were evolving by conducting the same surveys in 2014 and 2017.

In addition to the above-mentioned, we referred to a monthly magazine, New English Classroom (Koubunken) that has often featured the problem.

\section{METHODS AND RESULTS}

We used almost the same questions as in 2014 and added questions, taking into consideration the $6^{\text {th }}$ year of implementation. We researched schools, assistant language teachers (ALTs) and English Activity supporters (EASs). We sent research papers to one of the schools in every city throughout Japan. All the research data was returned by fax. The response rate and other basic data are as follows:

\subsection{The Research Method and Response Rate}

Table 1

\begin{tabular}{lll}
\hline Research date & February to March, 2014 & January to February, 2017 \\
\hline Research method & $\begin{array}{l}\text { Sent three papers to primary schools and } \\
\text { asked to return by fax. }\end{array}$ & $\begin{array}{l}\text { Sent three papers to primary schools and } \\
\text { asked to return by fax. }\end{array}$ \\
\hline Research target & $\begin{array}{l}\text { 800 cities and research surveys sent to one } \\
\text { school in every city-for primary schools, }\end{array}$ & $\begin{array}{l}\text { 800 cities and research surveys were sent to } \\
\text { one school in every city-for primary schools, } \\
\text { ALTs and EASs. }\end{array}$ \\
\hline ALTs and EASs. & $\begin{array}{l}\text { 1.212 public primary schools (26.3) } \\
\text { Response rate }\end{array}$ & 1.160 public primary schools (20.1) \\
2.79 ALTs (9.9) & 3.40 EASs (5.0) \\
\hline
\end{tabular}

\subsection{Results of the School Research and Considerations}

\subsubsection{Teachers in Charge}

Table 2

\begin{tabular}{lc}
\hline Q: Who teaches the English Activities to primary students? & 2017(N=212) Rate (\%) \\
\hline \multicolumn{2}{c}{ Answer category } \\
\hline (1) Only classroom teachers & 14.6 \\
\hline (2) Only teachers of English & 0.9 \\
\hline (3) Classroom teachers and EAS & 7.1 \\
\hline (4) Classroom teachers and ALT & 67.0 \\
\hline (5) Classroom teachers, ALT and EAS & 6.7 \\
\hline (6) Others & 3.7 \\
\hline
\end{tabular}

We asked about the structure and composition of the English Activity lessons and who was teaching the classes. Basically, more than $60 \%$ of classes were taught by classroom teachers together with ALTs. Classes where lessons were taught only by a classroom teacher comprised $14.6 \%$. And classes taught by an English teacher alone made up $0.9 \%$ of classes, which was the ideal that was hoped for by teachers. 


\subsubsection{Teaching Materials and Lesson plans}

\section{Table 3}

\begin{tabular}{lcc}
\hline \multicolumn{1}{c}{ Q: What teaching materials do you use? } & \multicolumn{2}{c}{ Rate (\%) } \\
\hline \multicolumn{1}{c}{ Answer category } & $2014(\mathrm{n}=160)$ & $2017(\mathrm{n}-212)$ \\
\hline (1) Use only Hi, friends! with textbook plan & 35.6 & 41.2 \\
\hline (2) Use only Hi, Friends! with original plan & 23.1 & 26.2 \\
\hline (3) Use Hi, friends! and original materials & 29.4 & 29.4 \\
\hline (4) Use only original materials & 2.5 & 2.3 \\
\hline (5) Use other ready-made materials & 9.4 & 0.9 \\
\hline
\end{tabular}

*Hi, friends: A textbook for primary students made by MEXT

MEXT prepared " $H i$, friends!" as the textbook for EL Activities in 2012 to enrich English Activity lessons and distributed it to every primary school in Japan. When we researched in 2014, there were still some schools that used original materials but in 2017 almost all the schools used only "Hi, friends!". They used only the manual plan that MEXT had made.

The research in 2014 indicated that the originality of each school was being lost rapidly and the tendency has been increasing year by year. However, it is also pointed out that there were still a few public primary schools using their own original materials.

\subsubsection{The Content Used in the Lessons}

Table 4

\begin{tabular}{lcc}
\hline \multicolumn{1}{c}{ Q: What content in the category do you teach? } & \multicolumn{2}{c}{ Rate $(\%)$} \\
\hline \multicolumn{1}{c}{ Answer Category } & $2014(\mathrm{n}=160)$ & $2017(\mathrm{n}=212)$ \\
\hline (1) To teach how to write the alphabet & 62.5 & 71.7 \\
\hline (2) To teach phonics* & 23.8 & 42.5 \\
\hline (3) Easy grammar & 24.4 & 28.8 \\
\hline (4) Other foreign languages except English & 16.3 & 14.2 \\
\hline
\end{tabular}

*phonics: a teaching method relating to spelling and pronunciation

"Hi, friends!" dealt with letters and teachers used letters in their lessons. However, MEXT insisted that teachers should not use letters when they teach English to children in primary schools. In the lessons, children wanted to read and write letters eagerly and the MOE changed the method. The tendency was the same as 3 years before. The percentage of classes using phonics greatly increased because they were taken from the textbook, "Hi, friends!". Other foreign languages were not being used much in the lessons.

3.2.4. Teachers in Charge of the Lesson Planning

Table 5

\begin{tabular}{lcc}
\hline \multicolumn{1}{c}{ Q: Who wrote the teaching plans? } & \multicolumn{2}{c}{ Rate $(\%)$} \\
\hline \multicolumn{1}{c}{ Answer Category } & $2014(\mathrm{n}=160)$ & $2017(\mathrm{n}=212)$ \\
\hline (1) Classroom teachers & 37.5 & 47.6 \\
\hline (2) Through teachers' discussions & 13.1 & 14.2 \\
\hline (3) Teachers of English & 18.8 & 24.5 \\
\hline (4) ALTs (Native speakers of English) & 32.5 & 44.3 \\
\hline (5) Other & 18.4 & 6.1 \\
\hline
\end{tabular}

According to the official course of study for primary school, classroom teachers or teachers of English had to write the teaching plans. However, it is a little hard for classroom teachers to make their own lesson plans because most of them have no experience teaching English. They have to create their teaching plans in English when they teach English to children, alongside the ALTs.

The ratio of classroom teachers that make teaching plans was increasing and also the ratio of ALTs was increasing although the course of study did not indicate the role of the ALTs in making teaching plans. Many local boards of education contracted with staffing agencies and the agencies made teaching plans for the schools, and so the English lessons were done according to those plans.

\subsection{Results of the ALT Research and Considerations}


We asked ALTs 8 questions and they answered sincerely with a lot of comments and opinions in English. We translated them into Japanese and summarized them.

3.3.1. Status of ALTS

Table 6

\begin{tabular}{lcc}
\hline \multicolumn{1}{c}{ Q: What is your status? } & \multicolumn{2}{c}{ Rate $(\%)$} \\
\hline Answer Category & $2014(\mathrm{n}=79)$ & $2017(\mathrm{n}=97)$ \\
\hline (1) English teachers hired by staffing agencies & 46.9 & 55.6 \\
\hline (2) English teachers hired by schools & 48.0 & 24.7 \\
\hline (3) Just personal teachers & 1.3 & 2.1 \\
\hline (4) Volunteers near schools & 0.0 & 0.0 \\
\hline (5) Parents of school child & 0.0 & 3.1 \\
\hline (6) Others & 2.5 & 13.5 \\
\hline
\end{tabular}

(6) includes the answers of those hired by their board of education and they are the same answers as (2). The numbers of cities that hired ALTs through staffing agencies increased. There were a lot of problems regarding the contracts.

3.3.2. Cooperative Lesson Planning with Classroom Teachers $(C T)$

Table 7

\begin{tabular}{lccc}
\hline \multicolumn{2}{c}{ Q: Do you prepare for each lesson with your CT? } & \multicolumn{2}{c}{ Rate (\%) } \\
\hline \multicolumn{1}{c}{ Answer Category } & $2014(\mathrm{n}=79)$ & $2017(\mathrm{n}=97)$ \\
\hline (1) Always & 24.1 & 23.7 \\
\hline (2) Almost always but not enough & 7.6 & 16.5 \\
\hline (3) Sometimes & 36.6 & 40.2 \\
\hline (4) Never & 10.1 & 7.2 \\
\hline (5) Other & 21.6 & 12.4 \\
\hline
\end{tabular}

(5) contained the ALTs who worked at several schools in a week. They had no time to talk with teachers. More than $60 \%$ of ALTs had little time to discuss their classes.

3.3.3. Ways of Preparing the Lessons

Table 8

\begin{tabular}{lcc}
\hline \multicolumn{1}{c}{ Q: How do you prepare for lessons with classroom teachers? } & \multicolumn{2}{c}{ Rate $(\%)$} \\
\hline \multicolumn{1}{c}{ Answer Category } & $2014(\mathrm{n}=79)$ & $2017(\mathrm{n}=97)$ \\
\hline (1) Meeting and talking beforehand & 59.5 & 62.2 \\
\hline (2) Exchanging plans by fax beforehand & 5.1 & 3.6 \\
\hline (3) Exchanging plans by e-mail beforehand & 2.5 & 4.5 \\
\hline (4) Receiving the prepared lesson plan just before each lesson & 10.1 & 17.0 \\
\hline (5) Others & 22.8 & 12.7 \\
\hline
\end{tabular}

More than $60 \%$ of the schools, classroom teachers and ALTs prepared for lessons beforehand, but around 20\% of ALTs prepared for some just minutes before the lessons.

3.3.4. How ALTs Engage in Creating Lesson Plans

Table 9

\begin{tabular}{lcc}
\hline \multicolumn{1}{c}{ Q: Are you engaged in creating lesson plans? } & \multicolumn{2}{c}{ Rate $(\%)$} \\
\hline Answer Category & $2014(\mathrm{n}=79)$ & $2017(\mathrm{n}=97)$ \\
\hline (1) Yes, lesson preparation is left entirely up to me & 51.8 & 45.3 \\
\hline (2) Yes, I am expected to make some suggestions & 20.3 & 36.5 \\
\hline (3) Not at all. I just follow the prepared plans & 7.6 & 5.2 \\
\hline (4) Others & 20.35 & 13.0 \\
\hline
\end{tabular}

(4) Others answered that it depended on the schools. The ALTs visited two or three schools a week and helped the classroom teachers. In many schools, the classroom teachers had to lead their classes.

3.3.5. Team-Teaching (TT) Situations 
Table 10

\begin{tabular}{lcc}
\hline \multicolumn{1}{c}{ Q: Do you teach in a team-teaching setting? } & \multicolumn{2}{c}{ Rate $(\%)$} \\
\hline \multicolumn{1}{c}{ Answer Category } & $2014(\mathrm{n}=79)$ & $2017(\mathrm{n}=97)$ \\
\hline (1) Assist classroom teachers as an ALT & 45.6 & 49.4 \\
\hline (2) I am told to play a main role & 30.4 & 31.0 \\
\hline (3) Not TT but I teach by myself & 13.9 & 8.3 \\
\hline (4) Others & 10.1 & 11.3
\end{tabular}

Half of the schools taught EL Activities in a TT setting. But more than $30 \%$ of ALTs mainly taught EL Activities themselves and around $10 \%$ of ALTs taught the English lessons completely by himself or herself. This showed that the government forced classroom teachers to teach but in actuality, locally it was a little difficult for teachers to do so.

\subsection{Results of the English Supporter Research and Considerations}

We also asked English Activity supporters (EASs) about their work. The answer rate was $4.9 \%$ and this number was almost the same as the situation throughout Japan. It meant that only 5\% of local governments hired EASs. 3.4.1. Status of EASs

\begin{tabular}{lcc}
\hline \multicolumn{2}{c}{ Table 11} & \multicolumn{2}{c}{ Rate $(\%)$} \\
\hline \multicolumn{1}{c}{ Answer Category } & $2014(\mathrm{n}=36)$ & $2017(\mathrm{n}=40)$ \\
\hline (1) Hired by a staffing agency & 2.8 & 5.0 \\
\hline (2) Personal private English teacher & 11.1 & 25.0 \\
\hline (3) English teacher near the primary school & 8.3 & 7.5 \\
\hline (4) Just citizen & 27.7 & 30.0 \\
\hline (5) Parents & 3.8 & 0.0 \\
\hline (6) Others & 44.4 & 32.5 \\
\hline
\end{tabular}

(6) Others contained supporters hired by local governments. Hence the number of citizens should be added. Almost all EASs were recruited by some kind of city bulletin.

3.4.2. Preliminary Meetings for Lessons the Teachers Have

Table 12

\begin{tabular}{lcc}
\hline \multicolumn{2}{c}{ Q: Do you have preliminary meetings for the lessons? } & \multicolumn{2}{c}{ Rate $(\%)$} \\
\hline \multicolumn{1}{c}{ Answer Category } & $2014(\mathrm{n}=36)$ & $2017(\mathrm{n}=40)$ \\
\hline (1) Always & 16.7 & 15.0 \\
\hline (2) Almost always but not enough & 66.6 & 67.5 \\
\hline (3) Sometimes & 11.1 & 12.5 \\
\hline (4) Never & 2.8 & 2.5 \\
\hline (5) Other & 2.8 & 2.5 \\
\hline
\end{tabular}

The state of the preliminary meeting was almost the same as 3 years before. In this situation, almost all EASs were good at English. They could prepare the lessons themselves. Hence they could have preliminary meetings for a short time in Japanese.

\subsection{Results of the EL Activities Research and Consideration}

We asked principals, ALTs and EASs about the results of the EL Activities. 3.5.1. The Effects of the EL Activities on Schools that Principals Found

Table 13

\begin{tabular}{lcc}
\hline Q: What did you find as the effects of the EL activities? & \multicolumn{2}{c}{ Rate $(\%)$} \\
\hline \multicolumn{1}{c}{ Answer Category } & $2014(\mathrm{n}=160)$ & $2017(\mathrm{n}=212)$ \\
\hline (1) Children began to speak English positively & 68.1 & 72.4 \\
\hline (2) Children began to have contact with foreigners & 58.8 & 46.7 \\
\hline (3) Children were positive to take part in other lessons & 4.4 & 5.2 \\
\hline (4) Relations among the children became better & 21.9 & 16.0 \\
\hline 5) Teachers took a fresh look at teaching other subjects & 8.1 & 7.5 \\
\hline (6) Cooperation amongst the teachers in schools became \\
stronger because of the EL Activities
\end{tabular}




\begin{tabular}{lll}
\hline 7 Others & 5.6 & 6.1 \\
\hline
\end{tabular}

Children began not to have contact with foreigners (ALTs). Hence children were losing interest in speaking to foreigners.

3.5.2. The Effects of EL Activities for Schools that ALTs Thought Resulted

Table 14

\begin{tabular}{lcc}
\hline Q: What did you find as the effects of the EL activities? & \multicolumn{2}{c}{ Rate $(\%)$} \\
\hline \multicolumn{1}{c}{ Answer Category } & $2014(\mathrm{n}=79)$ & $2017(\mathrm{n}=97)$ \\
\hline $\begin{array}{l}\text { (1) Children began to have interest in foreign cultures } \\
\text { (2) Children enjoyed the opportunity to communicate in a } \\
\text { language other than Japanese }\end{array}$ & 16.8 & 16.5 \\
\hline $\begin{array}{l}\text { (3) Children learned to communicate positively outside of } \\
\text { the EL Activities }\end{array}$ & 13.1 & 24.7 \\
\hline $\begin{array}{l}\text { (4) Children began to have confidence in learning English } \\
\text { and preparing for junior high schools }\end{array}$ & 10.3 & 14.4 \\
\hline $\begin{array}{l}\text { 5) Children had a pleasant experience studying English } \\
\text { (6) Others }\end{array}$ & 10.3 & 4.1 \\
\hline
\end{tabular}

Children began to enjoy communicating in English but in other subjects they were losing interest. It meant that English Activity lessons were a kind of play or game for children.

3.5.3. The Effects of EL Activities for Schools that EASs Thought Resulted

\section{Table 15}

\begin{tabular}{lcc}
\hline \multicolumn{1}{c}{ Q: What did you find as the effects of the EL activities? } & \multicolumn{2}{c}{ Rate $(\%)$} \\
\hline \multicolumn{1}{c}{ Answer Category } & $2014(\mathrm{n}=36)$ & $2017(\mathrm{n}=40)$ \\
\hline (1) To lighten the burdens of classroom teachers & 60.0 & 80.0 \\
\hline (2) To coordinate between classroom teachers and ALTs & 42.9 & 47.5 \\
\hline $\begin{array}{l}\text { (3) To give own points of view different from classroom } \\
\text { teachers or ALTs }\end{array}$ & 40.0 & 42.5 \\
\hline (4) To support the understanding of students & 65.7 & 52.5 \\
\hline 5) Others & 0.0 & 2.5 \\
\hline
\end{tabular}

Classroom teachers were too busy and teaching English Activity lessons was hard work for them. It is obvious that EASs understood that well.

\subsection{Questions and Problems}

3.6.1 The Questions and Problems of the EL Activities for Schools that Principals Thought Resulted Table 16

\begin{tabular}{lcc}
\hline \multicolumn{1}{c}{$\begin{array}{c}\text { Q: What questions and problems did you find } \\
\text { as the results of EL activities? }\end{array}$} & \multicolumn{2}{c}{ Rate (\%) } \\
\hline \multicolumn{1}{c}{ Answer Category } & 2014(n=160) & 2017(n=212) \\
\hline (1) Shortage of teaching materials for lessons & 20.6 & 24.5 \\
\hline (2) Teachers didn't know how to teach & 17.5 & 27.8 \\
\hline (3) Shortage of time to prepare for lessons & 56.3 & 57.5 \\
\hline (4) Children wouldn't learn English & 3.8 & 7.5 \\
\hline (5) It was difficult to communicate with ALTs & 24.4 & 26.4 \\
\hline (6) Teachers didn't have confidence & 25.6 & 32.5 \\
\hline (7) The difference of ability among teachers & 38.1 & 47.2 \\
\hline (8) No opportunities to exchange teaching methods or & 33.8 & 27.4 \\
study lesson information & 0.6 & 0 \\
\hline (9) Difficult to get parents' understanding & 7.5 & 8.0 \\
\hline (10) Others
\end{tabular}

The percentage of answers in almost all categories increased. This meant that questions and problems were being actualized year by year. Especially the differences of ability among teachers was becoming greater and greater. 


\subsubsection{The Questions and Problems of EL Activities for Schools that ALTs Thought Resulted}

\section{Table 17}

\begin{tabular}{|c|c|c|}
\hline $\begin{array}{l}\text { Q: What questions and problems did you find } \\
\text { as the results of EL activities? }\end{array}$ & \multicolumn{2}{|c|}{ Rate $(\%)$} \\
\hline Answer Category & $2014(n=79)$ & $2017(n=97)$ \\
\hline $\begin{array}{l}\text { (1) Correspondence to the children who lost confidence } \\
\text { and passion for study }\end{array}$ & 24.6 & 16.6 \\
\hline (2) Communication with classroom teachers & 12.2 & 6.2 \\
\hline (3) Attach no importance to writings & 6.7 & 4.1 \\
\hline $\begin{array}{l}\text { (4) Correct the typical bad English pronunciation from } \\
\text { Japanese }\end{array}$ & 6.7 & 1 \\
\hline $\begin{array}{l}\text { (5) Lack of teaching programs made by Ministry of } \\
\text { Education or local governments }\end{array}$ & 6.7 & 3.1 \\
\hline (6) The contents of textbook were wrong & 6.7 & 4.1 \\
\hline $\begin{array}{l}\text { (7) Classroom teachers didn't have self-confidence in } \\
\text { English }\end{array}$ & 5.6 & 7.2 \\
\hline (8) Too few English lessons a week & 4.4 & 9.3 \\
\hline (9) Not teaching how to read English & 3.3 & 4.1 \\
\hline (10) Difference of teachers' attitude to classroom & 3.3 & 2.1 \\
\hline (11) Too many students in a class & 3.3 & 0 \\
\hline (12) Too difficult to explain in English & 3.3 & 7.2 \\
\hline (13) Shortage of time to master English & 3.3 & 0 \\
\hline (14) Difference of English ability among children & 3.3 & 3.1 \\
\hline (15) Children don't have confidence & 2.2 & 8.2 \\
\hline (16) It's difficult to control the classroom & 0 & 9.3 \\
\hline $\begin{array}{l}\text { (17) Lack of classroom teachers' motivation, negative and } \\
\text { uncooperative attitude }\end{array}$ & 0 & 7.2 \\
\hline $\begin{array}{l}\text { (18) Lack of classroom teachers' English knowledge and } \\
\text { teaching method }\end{array}$ & 0 & 6.2 \\
\hline
\end{tabular}

The relations between ALTs and classroom teachers were becoming better but the attitude of classroom teachers towards EL Activities and the control of the classroom were becoming worse for ALTs. The success or failure of teaching depended on classroom teachers. 'The Report of Study Research on the Situation of ALTs in Primary, Secondary and High schools in Japan' (Yoshida, et al. 2015 \& 2017) showed this problem as the highest percentage. 3.6.3 The Questions and Problems of EL Activities for Schools that English Supporters Thought

Table 18

\begin{tabular}{lcc}
\hline $\begin{array}{c}\text { Q: What questions and problems did you find } \\
\text { as the results of EL activities? }\end{array}$ & \multicolumn{2}{c}{ Rate $(\%)$} \\
\hline \multicolumn{1}{c}{ Answer Category } & $2014(\mathrm{n}=36)$ & $2017(\mathrm{n}=40)$ \\
\hline (1) Lack of teaching materials for lessons & 22.9 & 17.5 \\
\hline (2) I don't know how to assist teachers & 5.7 & 0 \\
\hline (3) Lack of time to discuss about the lessons & 40.0 & 37.5 \\
\hline (4) Children didn't study English positively & 5.7 & 2.5 \\
\hline (5) It's difficult to communicate with ALTs & 0.0 & 0.0 \\
\hline (6) It's difficult to communicate with classroom teachers & 0.0 & 0.0 \\
\hline (7) The difference of ability by teachers & 13.9 & 35.0 \\
\hline (8) There are no chances to exchange methods or study & 42.9 & 45.0 \\
information with others & & 20.0 \\
\hline (9) The role of supporters is unclear & 5.7 & 15.0 \\
\hline (10) Others & 20.0 & \\
\hline
\end{tabular}


As a whole, the relations between classroom teachers and English Activity supporters were becoming better. However, they thought that the role of assistants was becoming unclear. Some classroom teachers did well with them but others entrusted them and shifted their work onto assistants.

\subsection{How to Make Improvements}

We asked principals, ALTs and EASs about how to make improvements on such problems. As a whole, they answered according to their practical experiences.

\subsubsection{The Improvements that Principals Wanted}

Table 19

\begin{tabular}{lcc}
\hline \multicolumn{1}{c}{ Q: What improvements do you want to see happen? } & \multicolumn{2}{c}{ Rate $(\%)$} \\
\hline \multicolumn{1}{c}{ Answer Category } & $2014(\mathrm{n}=169)$ & $2017(\mathrm{n}=212)$ \\
\hline (1) A budget to keep materials & 31.3 & 29.7 \\
\hline (2) Proper study of materials and methods & 55.6 & 59.9 \\
\hline (3) To allow teachers to experience going abroad & 10.0 & 5.2 \\
\hline (4) To hire more teachers of English & 48.8 & 63.2 \\
\hline (5) To have more time to prepare lessons & 51.3 & 50.5 \\
\hline (6) To improve teachers' English abilities & 57.5 & 61.8 \\
\hline (7) Thoughtfully arrange usage of ALTs & 33.8 & 36.8 \\
\hline (8) To increase the number of EASs & 18.8 & 23.6 \\
\hline (9) To cooperate with junior high schools & 34.4 & 29.2 \\
\hline (10) To narrow the gap among regions & 7.5 & 8.0 \\
\hline (1) Others & 2.5 & 1.4 \\
\hline
\end{tabular}

In total, the percentages were higher than 3 years previous. Many principals especially wanted to hire more teachers of English. They thought it was difficult for classroom teachers to teach English.

\subsubsection{The Improvements that ALTs Thought Needed}

Table 20

\begin{tabular}{|c|c|c|}
\hline Q: What improvements do you want to see happen? & \multicolumn{2}{|c|}{ Rate $(\%)$} \\
\hline Answer Category & $2014(n=79)$ & $2017(n=97)$ \\
\hline (1) Teach writing & 10.1 & 4.1 \\
\hline $\begin{array}{l}\text { (2) Efficient and effective use of Team Teaching with } \\
\text { ALTs }\end{array}$ & 10.1 & 10.3 \\
\hline (3) Teach phonics & 8.9 & 4.1 \\
\hline $\begin{array}{l}\text { (4) Classroom teachers or ALTs explain lessons in } \\
\text { Japanese }\end{array}$ & 7.6 & 5.2 \\
\hline (5) Improve communications with classroom teachers & 7.6 & 3 \\
\hline (6) Improve teachers' classroom management skills & 7.6 & 3 \\
\hline (7) Increase lessons to twice a week & 6.3 & 7.2 \\
\hline (8) Improve teachers' English skills & 5 & 4.1 \\
\hline (9) Increase time to discuss lesson planning & 5 & 0 \\
\hline (10) Decrease number of students in a class & 3.8 & 0 \\
\hline $\begin{array}{l}\text { 11) Develop classroom teachers' positive attitude towards } \\
\text { teaching English Activities }\end{array}$ & 2.5 & 2 \\
\hline $\begin{array}{l}\text { (12) Increase the number of teachers who are skilled to teach } \\
\text { English }\end{array}$ & 2.5 & 8.2 \\
\hline (13) Review the lessons & 2.5 & 0 \\
\hline $\begin{array}{l}\text { (14) Thoroughly monitor students' current abilities and } \\
\text { knowledge }\end{array}$ & 2.5 & 0 \\
\hline (15) Increase chances to use English outside the classroom & 2.5 & 0 \\
\hline (16) Study English Activities in every grade & 2.5 & 4.1 \\
\hline (17) Revise the curriculum & 0 & 8.2 \\
\hline
\end{tabular}




\begin{tabular}{llc}
\hline (18) Use better materials & 0 & 7.2 \\
\hline (19) ALTs should learn how to teach & 0 & 5.1 \\
\hline (20) Put importance on students' self-respect & 0 & 2 \\
\hline
\end{tabular}

ALTs also thought it was better to increase the number of teachers who have the ability to teach English. Another point of improvement would be to make the curriculum and materials better.

3.7.3. Improvements That EASs Thought Were Needed

Table 21

\begin{tabular}{lcc}
\hline \multicolumn{1}{c}{ Q: What improvements do you want to see happen? } & \multicolumn{2}{c}{ Rate $(\%)$} \\
\hline \multicolumn{1}{c}{ Answer Category } & $2014(\mathrm{n}=36)$ & $2017(\mathrm{n}=40)$ \\
\hline (1) Don't use volunteers but paid workers & 2.9 & 7.5 \\
\hline (2) Continuous employment & 28.6 & 45.0 \\
\hline (3) Study about materials and methods & 42.9 & 50.0 \\
\hline (4) Teach as licensed teachers & 25.7 & 45.0 \\
\hline 5) More time to prepare lessons & 22.9 & 30.0 \\
\hline (6) Others & 0.0 & 5.0 \\
\hline
\end{tabular}

EASs were almost always hired as part-time workers. They had to move to other schools every year according to the schools' needs. They knew English well, but did not know how to teach English to primary students. They also wanted to teach as licensed teachers.

3.7.4. The Principals' Requests for the National and Local Governments

Table 22

\begin{tabular}{lcc}
\hline \multicolumn{1}{c}{$\begin{array}{c}\text { Q: What did you request from the National } \\
\text { and Local Governments? }\end{array}$} & \multicolumn{2}{c}{ Rate (\%) } \\
\hline \multicolumn{1}{c}{ Answer Category } & $2014(\mathrm{n}=160)$ & $2017(\mathrm{n}=212)$ \\
\hline (1) To offer teaching materials & 29.4 & 41.0 \\
\hline (2) To hold training sessions with the boards of education & 26.9 & 27.8 \\
\hline (3) To take part in open study meetings of other schools & 24.4 & 17.9 \\
\hline $\begin{array}{l}\text { (4) To take part in training sessions held by private } \\
\text { organizations }\end{array}$ & 5.6 & 5.7 \\
\hline (5) To study abroad & 13.1 & 12.7 \\
\hline (6) To hire teachers of English & 47.5 & 60.4 \\
\hline (7) To hire ALTs & 30.0 & 29.7 \\
\hline (8) To hire EASs & 20.6 & 28.8 \\
\hline (9) Others & 8.1 & 2.8 \\
\hline
\end{tabular}

To hire teachers of English was the most urgent desire for primary schools in Japan followed by offering teaching materials.

\section{DISCUSSION AND CONCLUSION}

According to the research above, we explained the characteristics of EL Activities implemented between 2014 and 2017. Here we chose 7 points to outline the problems of EL Activities in Japanese primary schools and analyze the research results. All these points were taken from the research.

\section{Points to consider:}

\subsection{English Activities Should Be Taught by Classroom Teachers or Teachers of English}

The course of study by MEXT required that classroom teachers or teachers of English should teach English Activities. The Ministry's director always said in the training sessions that classroom teachers were best because they knew their students through spending time with them teaching multiple subjects. However, teaching English is totally different from teaching other subjects. They need specific training for that and, a matter of course, English language skills. The research showed that the more EL Activities were practiced, the more teachers of English were wanted by not only classroom teachers but also principals, ALTs and EASs. However, there are not enough well-prepared teachers at all. Therefore, even EASs were expected to act as the main teachers, because of their English language skills and capability in communicating with classroom teachers, ALTs and administrative staff in both English and Japanese. 


\subsection{The Role of ALTs and How to Best Use Them}

The course of study also said that teachers should cooperate with ALTs according to the situational needs of each lesson. Many local governments hired ALTs as per their budgets only, while more than $80 \%$ of schools adopted ALTs into their English Activity lessons. It was a good way for students to make contact with foreign peoples and different cultures. Research from 2014 already showed that students were greatly motivated to learn foreign languages. Moreover, the rate of children who enjoyed the opportunity to communicate in a foreign language increased almost $10 \%$. On that point, the significance of ALT was great. However, the number of ALTs who felt unable to control students increased significantly, and the rate of the ALTs who had difficulty in responding to students who lack confidence or motivation is still high. In addition to that, the answers from the principals showed that primary schools ultimately preferred teachers of English and EASs. Local governments hired ALTs yearly and schools had to correspond to this. They had to discuss teaching in English even though they were not good at English. They wanted the same ALTs to come back every year.

\subsection{The Role of English Supporters}

Many of ALTs could not speak Japanese well and it was difficult to teach English Activities using Japanese. That made them difficult to correspond with students well. They were also supposed to use only English. But this research showed that ALTs felt the necessity to use Japanese in their lessons and the importance of smooth and sufficient communication between classroom teachers and them. Herein EASs could play the important role of a coordinator utilizing their language skills in both Japanese and English.

However, they were hired as part-time supporters and their status was unclear. Some classroom teachers asked them to mainly teach the lessons and others asked to them to only make materials. That could have made them unmotivated through no fault of their own. This was also due to financial problems. Only $5 \%$ of local governments hired EASs.

\subsection{Students Who "Hate" English in Primary School}

About $80 \%$ of the Japanese primary students appeared to eagerly learn English (Benesse, 2015). However, in our research, teachers and ALTs who were actually teaching classes revealed that the reality was not so positive and there were a lot of students who "hated" English even from the beginning of primary school. Moreover, there were a lot of problems such as the huge gap among students' skills and willingness and teachers' abilities to motivate them. If the current situations did not improve, the number of the students who "hated" English would increase. The research showed that not only principals but ALTs were troubled by this problem. Public schools should cultivate all students' abilities and interests in language learning. Urgent improvement is strongly required.

\subsection{Textbooks and Materials}

MEXT prepared the textbooks "Hi, friends! 1" and "Hi, friends! 2" for EL Activities in 2012. However, the research shows that classroom teachers and ALTs were not satisfied with the textbooks, commenting on their insufficient contents and the need for other teaching materials. Therefore, some local boards of education prepared their own textbooks and used them.

In 2018, MEXT provided every primary school with the second textbooks "We can! 1" and "We can! 2." It seemed to be a step forward, however, the teachers still had difficulties to utilize them in their lessons. In addition to that, from April 2020, new authorized textbooks will be used. Every local board of education has already chosen one textbook among seven offered. These textbooks will not be used for the EL Activities but only for English study as an academic subject. The EL Activities will start from the third grade of primary schools. We should explore how these new textbooks will work.

\subsection{Appointment of Teachers of English}

The research in 2014 showed that primary schools wanted teachers of English and the research in 2017 speeded up the necessity of it. This tendency was also shown in another study. (Eiken Foundation of Japan, 2015). English is a foreign language different from other subjects. If it is hard for classroom teachers to speak English, how much harder it must be to actually teach English.

Although principals are aware of the great capabilities classroom teachers have, when it comes to teaching English as a required subject, it is indispensable for schools to have specialized English teachers. That is what has been claimed throughout the six years of implementation of EL Activities.

\subsection{Early EL Activities and Curriculum}


In the survey, we asked about the introduction of the subject of English from the fifth grade and the start of the EL Activities from the third grade. Many principals in primary schools had anxieties and doubts about that especially because of the lack of teaching competencies and sufficient time for preparations, and the difficulty in communicating with ALTs, the result showed. Since there have been no concrete and major improvements on the problems of foreign language education in primary schools in Japan, the principals represent those who take part in EL Activities who hope to cultivate every student's willingness to learn a foreign language and communicate with people from different cultural backgrounds.

Since the introduction of English Education into public primary schools was suggested by The Provisional Education Council in 1986, there have been revisions of the course of study and implementations of different forms of English education. However, our research has revealed that MEXT has not adequately discussed their consequences, nor allotted the necessary budget for precise and satisfying preparations for proper implementation. To our regret, despite such current conditions, the primary school English curriculum as an academic subject will commence from April, 2020.

This research is a little behind the times, however, currently, it is apparent that we still have the same problems that need urgent solutions in many of the ways we mentioned above. At this point we should conduct an even more detailed research study on the issues and continue to require concrete reforms.

\section{REFERENCES}

Benesse Education General Institute (2015). The Research on English Study in Primary Schools in Japan.

Eiken Foundation of Japan (2015). The Research of Present Situation on English Activities in Elementary School in Japan. Retrieved from the website of Eiken Foundation of Japan: https://www.eiken.or.jp/center_for_ research/pdf/market/elementary_press_2712.pdf

Japanese Ministry of Education, Culture, Sports, Science and Technology (2012). Hi, friends! 1 and 2.

Japanese Ministry of Education, Culture, Sports, Science and Technology (2016a). We Can! 1 and 2, Let's Try! 1 and 2 .

Japanese Ministry of Education, Culture, Sports, Science and Technology (2016b). Inspection of English Education Situation in Japan.

Kano, A., \& Ozeki, H. (2018). Insights from Elementary School ALTs in Japan. JES Journal, 18, 116-131. The Japan Association of English Teaching in Primary Schools.

Machida, T., \& Uchida, H. (2015). Developing of an In-Service Training Course Focusing on Alleviating Teachers' Foreign Language Anxiety. JES Journal, 15, 34-49. The Japan Association of English Teaching in Primary Schools.

New English Teachers' Association (2019) Serial Articles: The Reality of English Classrooms in Japan. The New English Classroom, No.596-607, Kobunken.

New English Teachers' Association. (2017). Featured Articles: Hope for English Education in Japanese Primary Schools. The New English Classroom, No.579, Honnoizumisha.

New English Teachers' Association. (2019). Featured Articles: How to Start Teaching English Alphabet. The New English Classroom, No.595, Kobunken.

Takiguchi, M., \& Machida, J. (2018) Present Situation and Issues of English Language Activities in Primary Schools After 6 Years of Implementation - Through the Research on English Language Activities in Primary Schools Annual Report of the The Shiraume Gakuen University and College, Center for Education and Welfare Studies, 23, 3-16. The Shiraume Gakuen University and College, Center for Education and Welfare Studies.

Takiguchi, M., Machida, J., \& Takiguchi, Ma. (2014). Present Situation and Issues of English Language Activities after 3 Years of Implementation - Through the Research on English Language Activities in Primary Schools. Annual Report of the The Shiraume Gakuen University and College, Center for Education and Welfare Studies, 19, 16-29. The Shiraume Gakuen University and College, Center for Education and Welfare Studies.

Yonezaki, M., Tara, S., \& Tsukuda, Y. (2016). Primary School Teachers' Anxiety about Teaching English as a Compulsory Subject and Teaching English to Middle-Grade Students: Structuring and Transition. JES Journal, 16, 132-146. The Japan Association of English Teaching in Primary Schools.

Yoshida, K., Kano, A., Izumi, S., Shimizu, T., et al. (2015, 2017). The Report of Study Research on the Situation of ALTs in Primary, Secondary and High schools in Japan. Sophia University. Retrieved from the website of Buneido: https://www.bun-eido.co.jp/aste/alt_final_report.pdf 